Available online on 15.09.2018 at http://jddtonline.info

Journal of Drug Delivery and Therapeutics

Open Access to Pharmaceutical and Medical Research

C) 2011-18, publisher and licensee JDDT, This is an Open Access article which permits unrestricted non-commercial use, provided the original work is properly cited

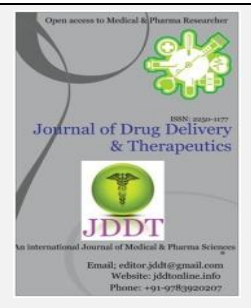

Open $\bigcirc$ Access

Research Article

\title{
Therapeutic Evaluation of Navan Nasya in Ardit W.S.R. to Facial Paralysis
}

\section{Dr. Kanungo Neeraj ${ }^{1}$, Dr. Kanungo Vijayata ${ }^{2}$}

${ }^{1}$ Asst. Professor, Department of Kayachikitsa, Govt. (Auto.) Ashtang Ayurved College Lokmanya Nagar, Indore (M.P.) 452009, India.

${ }^{2}$ Asst. Professor, Department of Panchakarma, Pt. Late Shiv Shaktila Sharma Ayurved College, Ratlam (M.P.), India.

\begin{abstract}
Ayurveda is sciences of medicine and health practicing anciently and it possessing effective methods for the treatment of various diseases. Ayurveda not only offer approaches for the management of curable diseases but also encompasses knowledge of incurable diseases. Panchakarma is one of the therapies of ayurveda which purify body and cleans all shrotas even at cellular level. Panchakarma therapy involves many sub therapies such as; Navannasya which is very useful in the management of various diseases such as; facial paralysis which involves weakness of facial muscles resulting from temporary or permanent loss of facial nerve. The study was planned to measure efficacy of navannasya in the treatment of Arditroga and it was found that navannasya gives good results in Ardit or facial paralysis. Some patient of cured effectively after the treatment with Navannasya.
\end{abstract}

Keywords: Ayurveda, Ardit, Facial Palsy, Panchakarma, Navannasya.

Article Info: Received 29 June, 2018; Review Completed 12 Aug 2018; Accepted 120 Aug 2018; Available online 15 Sep 2018

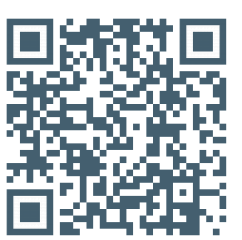

\section{Cite this article as:}

Kanungo N, KanungoV, Therapeutic Evaluation of Navan Nasya in Ardit W.S.R. to Facial Paralysis, Journal of Drug Delivery and Therapeutics. 2018; 8(5):284-287 DOI: http://dx.doi.org/10.22270/jddt.v8i5.1870

\section{*Address for Correspondence:}

Dr. Neeraj Kanungo, Asst. Professor, Department of Kayachikitsa, Govt. (Auto.) Ashtang Ayurved College Lokmanya Nagar, Indore (M.P.) 452009, India

\section{INTRODUCTION}

The current scenario of disciplinary life pattern, excessive movements with vehicles, use of wrong postures, lack of exercises, anxiety and strain etc. leads various diseases including; Pakshawadha (Paralysis)/Ardit (facial paralysis). Ardit (facial paralysis) is vatavyadhi associated with or without Pakshawadha commonly classified under neurological disorder. In modern science Ardit may be correlated with facial palsy involving weakness of cranial nerve or facial nerve. The condition involves drop angle of mouth, continuous salivation, problem in closing eyes and loss of nasolibial fold ${ }^{1-4}$.

Ayurveda the holistic approach of disease management generally described use of snehan-swedan, vastikarma and nasya for the management of vatvyadhi. According to Charak Nasyakarana (Navan Nasya) may offer beneficial effects in the specific treatment of Arditroga. Nasya therapy offer symptomatic relief in Ardit (facial paralysis) since it offers effective body purification especially at upper body part ${ }^{5-9}$.

\section{Aim and Object:}

1. To observe the effect of Navannasya in the management of Ardita.

2. To standardize the methodology of Navannasya.

\section{MATERIAL AND METHODS}

1. 20 patients of Ardita fulfilling the criteria of diagnosis were registered from O.P.D. of Govt. Asthang Ayurved College, Indore (M.P.).

2. A specific research proforma was prepared incorporating all the signs \& symptoms based on both Ayurveda and modern literature. 
3. External massage for 5 minutes was done on selected patients of Arditroga with mahanarayan tail, after that mradu swedan was performed using hot water bag or nadiyantra.

4. The patient was placed in the supine position with head lowered by placing a pillow below the neck and feet slightly raised. The eyes were covered with the cotton or folded cloth.

5. The shodhannasya (by Katphalpowdar) was fixed as follows:

\section{Dhapananasya/Pradhamananasya:}

- $\quad$ Katphal powder-three muchyutii:

Dose: According to Videha the dose of Dhmapana Nasya is three Muchuti (3 pinch).

- Navannasya/Snehannasya:

Dose:-Anutail-8 drops in each nostril.

6. After giving nasya, patient was instructed to lie in the same position for 1 minute then patient was allowed to expel out the morbid dosha.

7. At the end of the $21^{\text {st }}$ days course of Nasya therapy the total effect of study was assessed.

\section{ASSESSMENT CRITERIA}

The assessment of the result was done by observing clinical signs and symptoms of Ardit as follows:
1. Mukhvakrata
2. Nasavakrata
3. Greevavakrata
4. NetraStabdhata
5. Waksang
6. NetraStabdhata
7. Lalasrava
8. KshawathuNigrah

Following examinations were also included in the assessment criteria:

1. Unable to close eyes

2. Unable to whistle

3. Unable to inflate mouth.

\section{RESULTS}

20 patients of Arditaroga were selected for the study, the general data of the participants mentioned in Table 1.

Table 1: General Data of Patients:

\begin{tabular}{|c|l|l|l|}
\hline S. No. & \multicolumn{1}{|c|}{ Particular } & \multicolumn{1}{c|}{ Specification } & \multicolumn{1}{c|}{ Data of patient } \\
\hline 1. & Age & Range in year & $30-70$ \\
2. & Sex & Male & $16(80 \%)$ \\
& & Female & $4(20 \%)$ \\
3. & Marital Status & Married & $18(90 \%)$ \\
4. & Economic Status & Poor & $3(15 \%)$ \\
& & Middle & $15(75 \%)$ \\
5. & Habitat & Rich & $2(10 \%)$ \\
& & Urban & $15(75 \%)$ \\
6. & Addiction & Rural & $5(25 \%)$ \\
& & Tea & $5(25 \%)$ \\
& & Smoking & $10(50 \%)$ \\
& & Alcohol & $3(15 \%)$ \\
7. & Chronicity & Sleeping Pills & $2(10 \%)$ \\
& & No Addiction & 0 \\
8. & Diet & Below 1 month & $12(60 \%)$ \\
& & (1-6) month & $8(40 \%)$ \\
& & Above 6 month & 0 \\
& & Vegetarian & $15(75 \%)$ \\
& & Mixed & $5(25 \%)$ \\
\hline
\end{tabular}

\section{DISCUSSION}

In this clinical trial 20 patients of Ardit were treated to measure effect of Navannasya. Katphal powder was used as dhampananasya/Pradhamananasya and anutail was used as snehannasya.

1. All the 20 patients of this series belonged to the age group of 30-70 years and most of the patients (80\%) were male, so it can be say that the Ardiatroga is slightly more common in male than female.
2. Majority of the patients $(75 \%)$ were from urban area while $25 \%$ were from rural area. It may be possible due to the exposure of pollution, gases like carbon monoxide and hydrocarbons.

3. In present study smokers were seen maximum while percentage of tea addicts and drunker were less. Smoking is neuro-degenerative \& has atherogenic properties therefore may initiate pathogenesis of neurological disorder. 
4. Majority of the patients $(75 \%)$ was vegetarian while $25 \%$ were taking mixed diet.

5. $60 \%$ of the patients were suffering from the disease for a month while $40 \%$ patients had the chronicity of 1-6 months.

6. All the patients (100\%) were having mukhvakrata and khsawathunigrah as mentioned in Table No. 2. Other main symptoms were observed as follows:
- Waksang and netrastabadhata $(90 \%)$

- $\quad$ Nasavakarta $(75 \%)$

- Vedana and lalasrav (40\%)

- Greevavakarta $(20 \%)$

Table 2: Percentage of Main Symptoms of Ardit amongst Participants:

\begin{tabular}{|c|l|c|c|}
\hline S. No. & \multicolumn{1}{|c|}{ Symptoms } & No. of Patients & \% \\
\hline $\mathbf{1 .}$ & MukhVakrata & 20 & 100 \\
$\mathbf{2 .}$ & Nasavakrata & 15 & 75 \\
$\mathbf{3 .}$ & Greevavarata & 4 & 20 \\
$\mathbf{4 .}$ & Vedana & 8 & 40 \\
$\mathbf{5 .}$ & Waksang & 18 & 90 \\
$\mathbf{6 .}$ & NetraStabdhata & 18 & 90 \\
$\mathbf{7 .}$ & Lalasrava & 8 & 40 \\
$\mathbf{8 .}$ & KshawathuNigrah & 20 & 100 \\
\hline
\end{tabular}

The other symptoms of Arditroga such as; problem to close eyes, to whistle and to inflate cheeks were observed in all patients (Table 3).

Table 3: Some Important Observations in Patients of Ardit (Facial Paralysis):

\begin{tabular}{|c|l|c|c|}
\hline S. No. & \multicolumn{1}{|c|}{ Observation } & No. of Patients & \% \\
\hline 1. & Unable to close the eyes & 20 & 100 \\
\hline 2. & Unable to whistle & 20 & 100 \\
\hline 3. & Unable to inflate cheeks & 20 & 100 \\
\hline
\end{tabular}

\section{Effect of Nasya therapy on symptoms of Ardit:}

At the end of therapy, vedana, lalasrav and kshawathunigrah were relieved completely while Nasavakrata 93\%, waksang 83\%, mukhavakrata 68\%, Greevavakrata $67 \%$ and netra-stabhdhata relieved $58 \%$
(Table No. 4). Relief was observed in special observations such as; unable to close eyes, unable to whistle and unable to inflate cheeks (Table No. 5). The total effects of therapy as per symptoms index mentioned in Table 6.

Table 4: Effect of Navannasya on Main Symptoms of Ardit Roga according to the Symptom Index:

\begin{tabular}{|c|l|c|c|c|c|}
\hline S. No. & \multicolumn{1}{|c|}{ Symptoms } & $\begin{array}{c}\text { S.I. } \\
\text { B.T. }\end{array}$ & $\begin{array}{c}\text { S.I. } \\
\text { A.T. }\end{array}$ & $\begin{array}{c}\text { Cured } \\
\text { S.I. }\end{array}$ & Effect in \% \\
\hline 1. & MukhVakrata & 62 & 20 & 42 & 68 \\
2. & NasaVakrata & 28 & 2 & 26 & 93 \\
$\mathbf{3 .}$ & Greevavakrata & 6 & 2 & 4 & 67 \\
$\mathbf{4 .}$ & Vedana & 8 & - & 8 & 100 \\
\hline $\mathbf{5 .}$ & Waksang & 36 & 6 & 30 & 83 \\
\hline $\mathbf{6 .}$ & NetraStabdhata & 48 & 22 & 26 & 58 \\
\hline $\mathbf{7 .}$ & Lalasrava & 8 & - & 8 & 100 \\
\hline $\mathbf{8 .}$ & KshawathuNigrah & 30 & - & 30 & 100 \\
\hline
\end{tabular}

Table 5: Effect of Navannasya on Special Observations of Ardit Roga according to Symptom Index

\begin{tabular}{|c|l|c|c|c|c|}
\hline S. No. & \multicolumn{1}{|c|}{ Symptoms } & $\begin{array}{c}\text { S.I. } \\
\text { B.T. }\end{array}$ & $\begin{array}{c}\text { S.I. } \\
\text { A.T. }\end{array}$ & $\begin{array}{c}\text { Cured } \\
\text { S.I. }\end{array}$ & Effect in \% \\
\hline 1. & Unable to close the eyes & 52 & 18 & 34 & 65 \\
2. & Unable to whistle & 40 & 4 & 36 & 90 \\
3. & Unable to inflate cheeks & 38 & 14 & 24 & 63 \\
\hline \multicolumn{2}{|c|}{ B.T. = Before Treatment A.T. = After Treatment } \\
\hline
\end{tabular}


Table 6: Total Effect of Navannasya on 20 Patients of Ardit according to Symptom Index:

\begin{tabular}{|c|c|c|c|c|}
\hline Case No. & S.I. B.T. & S.I. A.T. & Cured S.I. & Effect in \% \\
\hline 1. & 32 & 8 & 24 & 75 \\
\hline $\mathbf{2 .}$ & 38 & 14 & 24 & 68 \\
\hline $\mathbf{3 .}$ & 26 & 2 & 24 & 92 \\
\hline $\mathbf{4 .}$ & 46 & 12 & 17 & 74 \\
\hline $\mathbf{5 .}$ & 34 & 4 & 30 & 88 \\
\hline $\mathbf{6 .}$ & 50 & 12 & 19 & 76 \\
\hline $\mathbf{7 .}$ & 38 & 6 & 32 & 84 \\
\hline $\mathbf{8 .}$ & 48 & 12 & 36 & 75 \\
\hline $\mathbf{9 .}$ & 42 & 14 & 28 & 67 \\
\hline $\mathbf{1 1 .}$ & 50 & 12 & 19 & 76 \\
\hline $\mathbf{1 2 .}$ & 38 & 14 & 24 & 68 \\
\hline $\mathbf{1 3 .}$ & 48 & 12 & 36 & 75 \\
\hline $\mathbf{1 4 .}$ & 42 & 14 & 28 & 67 \\
\hline $\mathbf{1 5 .}$ & 40 & 8 & 32 & 80 \\
\hline $\mathbf{1 6 .}$ & 44 & 10 & 34 & 77 \\
\hline $\mathbf{1 7 .}$ & 36 & 12 & 24 & 67 \\
\hline $\mathbf{1 8 .}$ & 48 & 12 & 36 & 75 \\
\hline $\mathbf{1 9}$ & 32 & 8 & 24 & 75 \\
\hline $\mathbf{2 0 .}$ & 38 & 14 & 24 & 68 \\
\hline
\end{tabular}

\section{Overall Effect of Navannasya in Ardit}

It was observed that $65 \%$ patients were cured and $35 \%$ received marked improvement. The study confirmed that Nasya therapy offer beneficial effects up to some extent in the treatment of Arditroga as shown in Table No. 7.

\section{CONCLUSION}

Nasya therapy offered symptomatic relief in Arditroga and Navannasya possess beneficial effects in all aspect in the management of facial paralysis/Ardit. The appreciable outcomes of study suggested that further research on large population require to established pharmacological action of Navannasya in facial paralysis/Ardit.

Table 7: Total Effect of Navannasya in Facial Paralysis/Ardit.

\begin{tabular}{|c|l|c|c|}
\hline S. No. & \multicolumn{1}{|c|}{ Result } & No. of Patient & \% \\
\hline 1. & Cured (75-100\%) & 13 & 65 \\
\hline 2. & Markedly improved (50-74\%) & 7 & 35 \\
\hline 3. & Improved (25-49\%) & - & - \\
\hline 4. & Stable (1-2.4\%) & - & - \\
\hline 5. & Deterioration & - & - \\
\hline
\end{tabular}

\section{REFERENCES}

1. Astanga Hridaya: Sarvanga Sundara Commentary by Arundatta, Chowkhambha Sanskrit Series, Varanasi, 1992.

2. Astanga Samgraha: by Vriddha Vagbhatta, Hindi Commentary by Atrideva Vidhyalankara, 1992.

3. Bhavaprakash: Sastu Sahitya Vardhaka Karyalaya, $3^{\text {rd }}$ edition, 1982.

4. Charaka Samhita: with Vidyotini Hindi Commentary by Kashinath Shastri and Gorakhanath, Chaukhambha Bharti Academy, Varnasi, 2001.

5. Kasture H. S., Ayurvedic Panchkarma Vigyana, $5^{\text {th }}$ edition, Baidyanath Ayurveda Bhavan, Nagpur, 1997.
6. Sharngdhara Samhita: Edited by Siddhinandev Mishra, $1^{\text {st }}$ edition, Chaukhambha Orientatia, Varanasi, 2000.

7. Susruta Samhita: with Ayurveda Tatva Sandipika, Hindi commentary by Shastri A., Chaukhambha Sanskrit Samsthana, Delhi, 1998.

8. Harrison: Harrison's Principles of Internal Medicine, Anthony Fanci et al. Boucher, $14^{\text {th }}$ edition, 2000.

9. Davidson: Davidson's Principles and Practice of Medicine, by Christopher R.W., Edwards, 17 $7^{\text {th }}$ edition, 1997. 